\title{
Comparative physico-chemical, functional and structural characteristics of winged bean [Psophocarpus tetragonolobus DC] and soybean [Glycine max.] protein isolates
}

\begin{abstract}
The physicochemical (colour, bulk density, thermal properties, molecular sizes), functional (water and oil absorption, solubility, emulsifying and gelation properties) and secondary structural properties of winged bean isolate (W-ISO) were studied and compared with those of soybean isolate( $\mathrm{S}$-ISO) as reference. Results showed that W-ISO and S-ISO had extraction rates of 32.23 and $37.52 \mathrm{~g} / 100 \mathrm{~g}$, respectively, with corresponding protein content of 81.68 and $85.69 \%$ (dry weight basis). W-ISO and S-ISO had denaturation temperature and enthalpy of $105.53 \& 111.61{ }^{\circ} \mathrm{C}$, and $3.77 \& 3.30 \mathrm{~J}$ g-1,respectively. Both isolates showed comparable functional properties, but W-ISO had higher foaming and oil absorption properties whereas S-ISO had higher water absorption and surface hydrophobicity. FTIR spectroscopy showed that W-ISO is composed of $15.38 \% \alpha$-helices, $37.46 \% \beta$-sheets, $31.67 \%$ turns and $15.38 \%$ disordered secondary structures whereas S-ISO had $15.46 \% \alpha$-helices, $46.15 \% \quad \beta$-sheets, $30.78 \%$ turns and $7.69 \%$ unordered components. In addition to being a potential food ingredient comparable to soybean isolate, winged bean isolate can also be employed in foods where high foam volume is essential.
\end{abstract}

Keyword: Winged bean isolate; Winged bean seeds; FTIR; Soy isolate; Functional properties; Surface hydrophobicity 